\title{
EMPLOYEE COMPENSATION EVALUATION BASED ON COST OF LIVING ADJUSTMENT (COLA) IN RETAIL INDUSTRY BOGOR, INDONESIA
}

\author{
By: \\ Aldy Rizaldy ${ }^{1}$ \\ Lindawati Kartika ${ }^{2}$ \\ Roni Jayawinangun ${ }^{3}$ \\ Department of Management IPB University ${ }^{1 \& 2}$ \\ Department of Communication and Science Pakuan University ${ }^{3}$ \\ Email: \\ aldyrizaldy997@gmail.com
}

\begin{abstract}
The retail industry is a field that has a high contribution to the Indonesian economy. This research will examine the compensation based on the need for a decent living for retail workers. The purpose of this study is to (1) Analyze and evaluate the fulfillment of compensation (2) Creating a design and compensation strategy based on the requirements of decent living in Bogor. The type of data in this study is primary data (interview and questionnaires) and secondary data obtained from the website of Bogor, BPS, literature study, and relevant report. The method used is the descriptive analysis, control chart, and Grid ERRC. The results show that according to 60 components of Living Standards/KHL, only 53 items have been fulfilled and the rest (7 items are expected to be reviewed/Omited) and equal to Rp 2.753.000 which are below to Minimum Wage in Bogor. There is a priority in financial compensation and non-financial compensation, which are health benefits, holiday benefits, work accidents, and work incentives and non-financial compensation consists of career systems, work facilities, responsibilities, work status, working conditions. According to the control chart only $38 \%$ of the total respondents whose number of the COLA can be fulfilled above the average retail sector worker.
\end{abstract}

Keywords: Compensation, Control Chart, Standard of Living

\section{A. INTRODUCTION}

A large number of available workers enables an organization to choose the desired workforce. The absorption rate of manpower in Indonesia is still insufficient, as evidenced by the number of registered job seekers that are still far greater than the available job vacancies. With a large number of existing workers, it gives organizations/companies the choice of choosing the desired workforce. To get a workforce following the needs of the organization/company is compensation. The compensation is designed to attract, keep or retain employees. Compensation involves obtaining workers based on the company's organization's needs. In 
general, compensation is meant to attract and retain employees. It is determined based on the internal and external environments of organizations (Kartika, 2020b). This is a broader and comprehensive aspect compared to wages. For instance, it involves both financial and non-financial services, while wages prioritize financial rewards. Compensation is either a direct or indirect form of remuneration (Kartika, 2020a). It is the primary motivation for an employee to work and increase productivity. Moreover, it can be interpreted as all forms of income, directly or indirectly, received by employees for services provided to the company (Hasibuan, 2011).

Small and medium enterprises (SMEs) have the largest employment due to their strategic role in Indonesia's economic development (Bank Indonesia dan LPPI, 2015). The number of residents can influence economic development potential. Bogor is a large city with 5.965 .410 people, indicating a significant potential for developing small and medium industries (Sugiyono, 2012), such as the retail sector. Indonesia has a large retail market potential. The largest contribution to GDP is mainly from the industrial sector at $19,28 \%$, followed by the trade sector, $13 \%$. Therefore, the retail trade sector has the potential to be developed in a modern state (Badan Pusat Statistik, 2013).

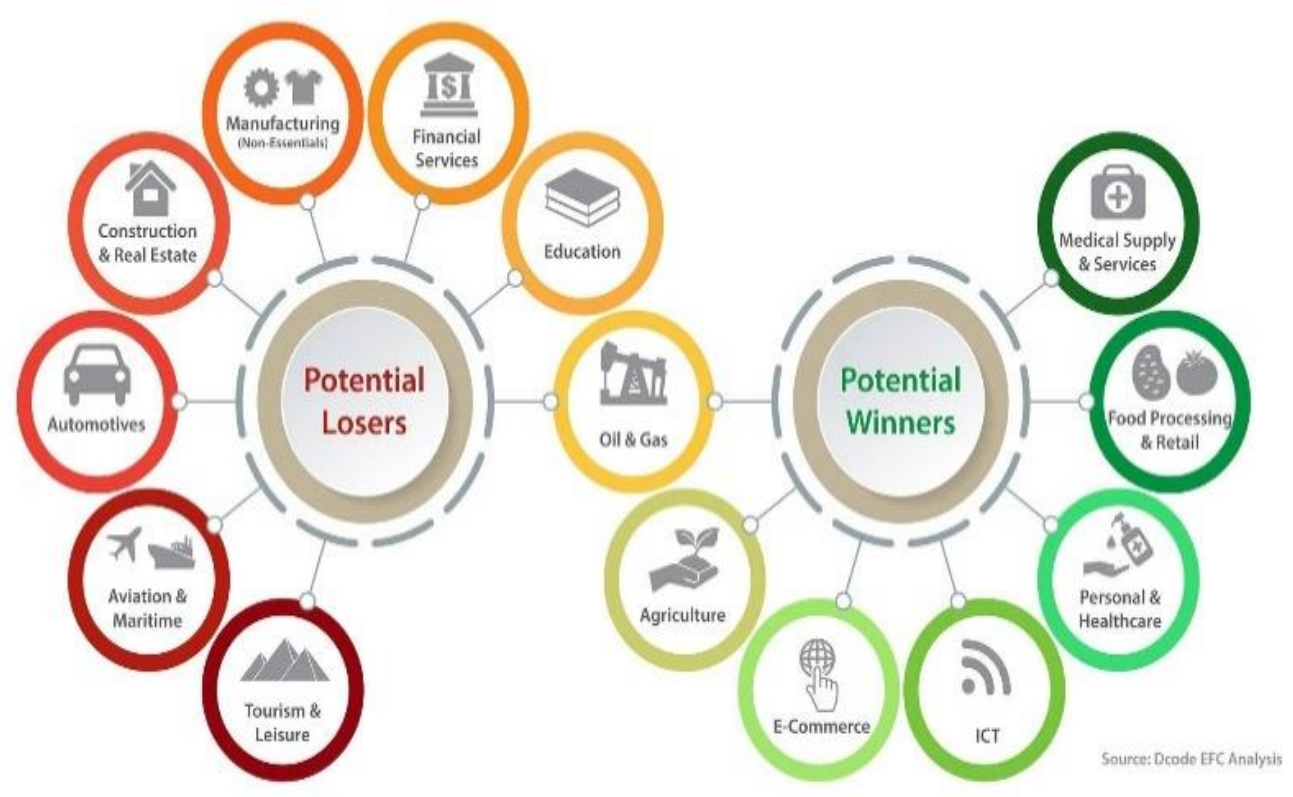

Source: Dcode EFC Analysis

Figure 1

\section{Potential Winners and Losers in The Short Term Covid 19}

Based on Figure 2, it can be seen that the retail business is included as potential winners even though it is in an uncertain situation such as the covid-19 outbreak, the retail business is still running because it is indeed one of the sectors that are very much needed by the community, so it is important for retail businesses. take advantage of the advantages and maximize these opportunities. The number of retails in Bogor in 2019 is 557 units with wages that must be received according to the predetermined minimum wage. 


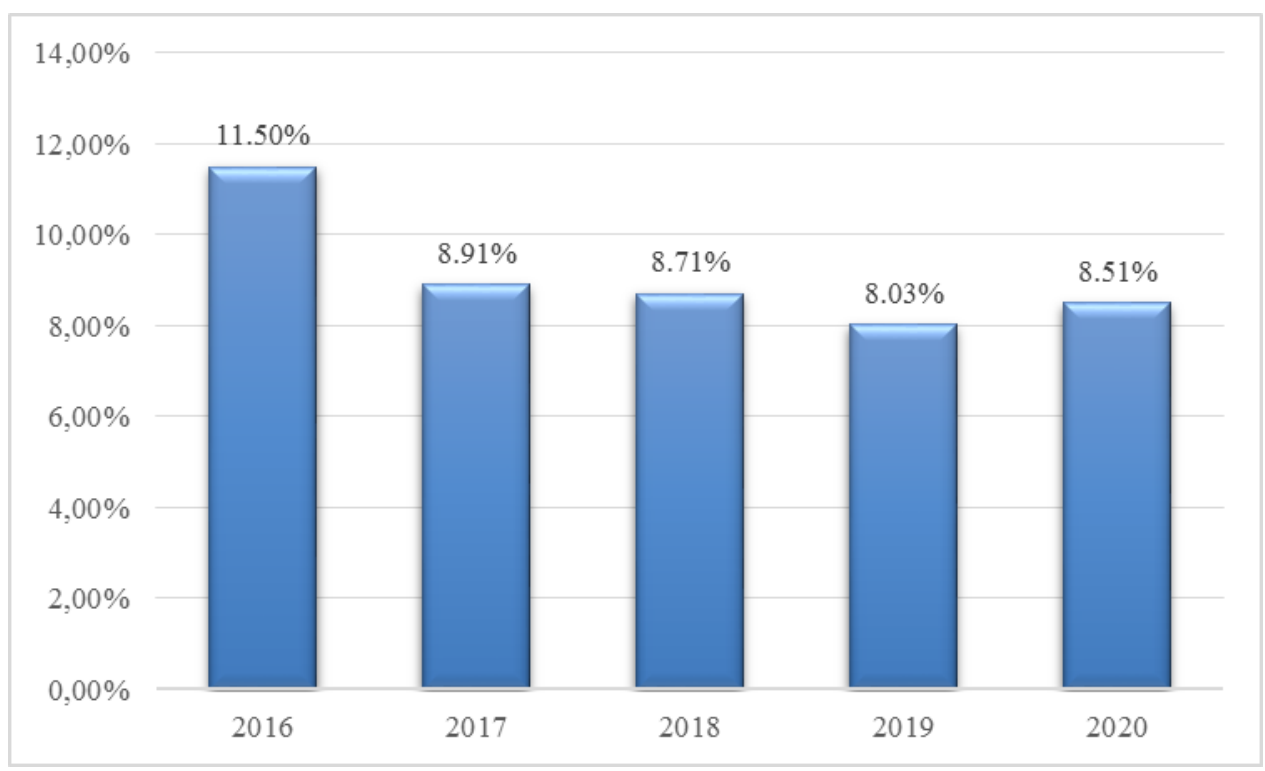

Figure 2

Increase in The Minimum Wage

The minimum wage in Indonesia has an average increment of $9.1 \%$, which can be a disturbing trend for employers. The existing wage policy relies on minimum wages based on the needs for Decent Living (DL) workers. The minimum wage is determined in PP No. 78 of 2015 concerning Wages (Izzaty \& Sari, 2013). Decree of the Minister of Manpower number 13 of 2012 stipulates that there are $60 \mathrm{KHL}$ items. Among them, 11 food and beverage items, 13 clothing items, 26 housing items, 2 educational items, 5 health items, 1 transportation item, and 2 items for recreation and savings. The demands of employers and workers are contradictory regarding wages, workers who want wages that are always increasing so want a change in the wage system of pay. The scope of this research is limited to a discussion related to the job value-based compensation system applied to the Bogor retail industry by taking only a few samples from the total retail in Bogor, besides that this study is also limited to discussing the components of the decent living needs which consist of 60 items.

\section{B. LITERATURE REVIEW}

\section{Decent Living Needs}

Decent Living Needs, hereinafter abbreviated as KHL, is the need for a single worker/laborer to be able to live physically properly within 1 month. Decent Living Needs in determining the minimum wage as follows based on the 2015 Ministry of Manpower regulation article 2 as follows (Menteri Tenaga Kerja Republik Indonesia, 2016):

1. Determination of the Minimum Wage by the Governor based on the KHL and with due observance of productivity and economic growth. 
2. In determining the minimum wage as referred to in paragraph (1), the Governor must discuss simultaneously and consider the following factors:

a) The KHL value obtained and determined from the survey results;

b) Macro productivity which is the result of a comparison between the amount of Gross Regional Domestic Product (GRDP) and the number of workers in the same period;

c) Economic growth is a growth in the value of GRDP;

d) Labor market conditions, the ratio of the number of job opportunities to the number of job seekers in a certain area in the same period;

e) The most disadvantaged (marginal) business condition is indicated by the development of the number of marginal businesses in a certain area in a certain period.

\section{Compensation}

Basic compensation is necessary to maintain employees with an adequate standard of living, but compensation also provides a tangible measure of the individual's value to the company. Compensation is a strategic human resource function that has a significant impact on other human resource functions (Blazovich, 2013). Compensation is not only in financial form but also in non-financial form. Direct financial forms are in the form of salaries, wages, commissions, and bonuses, while the indirect forms are insurance, social assistance, leave pay, pension, training, and so on. Besides, the non-financial form includes elements of the type of work and work environment. The elements of the type of work can include responsibilities, concerns, and rewards from the leadership. While the elements of the type of work environment include the comfort of working conditions, the distribution of the division of labor, and company policies. The compensation function does not operate separately. Rather, it is only on the components of the company's human resource system. Compensation professionals interact with members of varying consistency, including trade union representatives and top executives (Murty \& Hudiwinarsih, 2012).

\section{Salary Structure}

Adjustment of employee salaries can be done by providing salary increases following basic salary provisions, and cannot cause employees to experience a reduction in salary because this can be counter-productive between employers and employees (Retnowati \& Widia, 2012). Measurement of the salary structure can be seen from two things, namely range spread and mid to mid (midpoint differential), it is explained that range spread is a characteristic of the salary structure which describes the distance between the minimum and maximum value of the salary range. Whereas mid to mid is a characteristic of the salary structure design which draws the percentage difference between the midpoint values of the adjacent salary ranges. The job value of constructing a constructed test can theoretically be carried out by evaluating a set of jobs in a defined hierarchy where relative values have been agreed upon and by using two or more evaluation methods. 


\section{SME's (Small and Medium Enterprises)}

SME's is an acronym for Small and Medium Enterprises, a term that refers to the types of businesses engaged in their respective fields, here is a table that explains the differences between small and medium enterprises (Badan Pusat Statistika, 2020)

Table 1

SMEs classification based on criteria

\begin{tabular}{ccccccc}
\hline \multirow{2}{*}{ Criteria } & \multicolumn{2}{c}{ UU No. 20 Tahun 2008 } & \multicolumn{2}{c}{$\begin{array}{c}\text { International Finance } \\
\text { Corporation }\end{array}$} & \multicolumn{2}{c}{$\begin{array}{c}\text { Central Bureau of } \\
\text { Statistic }\end{array}$} \\
\cline { 2 - 6 } & $\begin{array}{c}\text { Small } \\
\text { Enterprise }\end{array}$ & $\begin{array}{c}\text { Middle } \\
\text { Enterprise }\end{array}$ & $\begin{array}{c}\text { Small } \\
\text { Enterprise }\end{array}$ & $\begin{array}{c}\text { Middle } \\
\text { Enterprise }\end{array}$ & $\begin{array}{c}\text { Small } \\
\text { Enterprise }\end{array}$ & $\begin{array}{c}\text { Middle } \\
\text { Enterprise }\end{array}$ \\
\hline $\begin{array}{c}\text { Omzet } \\
\text { (IDR) }\end{array}$ & $\begin{array}{c}>300 \\
\text { million }-\end{array}$ & $\begin{array}{c}>2,5 \\
\text { billion- } \\
\text { billion }\end{array}$ & $\begin{array}{c}>100 \\
\text { thousand }- \\
\text { billion million }\end{array}$ & $\begin{array}{c}>100 \\
\text { thousand- } \\
\text { million }\end{array}$ & - & - \\
\hline $\begin{array}{c}>50 \\
\text { Asset }\end{array}$ & $\begin{array}{c}>500 \\
\text { million- } \\
500\end{array}$ & $\begin{array}{c}>3 \text { million } \\
\text { million }-10\end{array}$ & $\begin{array}{c}>15 \\
\text { billion }\end{array}$ & $\begin{array}{c}>\text { million } \\
15 \text { billion }\end{array}$ & - & - \\
\hline $\begin{array}{c}\text { Labour } \\
\text { Amount }\end{array}$ & - & - & $11-50$ & $51-300$ & $5-19$ & $20-99$ \\
\hline
\end{tabular}

Source: Central Bureau of Statistic 2018

\section{Retail Industry}

Retail is any form of business that directs its marketing efforts to end consumers to sell goods or services (Johnson \& Distinguished, 2013). The retail business or retail business in Indonesia began to develop in the 1980s as the Indonesian economy began to develop. This arises as a result of growth in the middle class, which has resulted in a growing demand for supermarkets and department stores (convenience stores) in urban areas. The development of this business in the retail industry has also been accompanied by increasingly fierce competition between some retailers, both local and foreign, which have sprung up in Indonesia. The retail industry in Indonesia is currently growing with the increasing number of construction of new outlets in various places. The excitement of retail entrepreneurs in competing to invest in the construction of new outlets is not difficult to understand. With an average economic growth of over 3\% since 2000 and the inflation rate is controlled, it could be their reason that the Indonesian economy could strengthen again in the future. The liveliness of the Indonesian retail industry was marked by the opening of new outlets by foreign retailers such as Makro (Netherlands), Carrefour (France), and Giant (Malaysia, which was later also partnered with PT Hero Supermarket Tbk), which are spread across major cities. such as Jakarta, Makassar, Semarang, Bandung, Yogyakarta, and so on.

Based on the Presidential Regulation of the Republic of Indonesia Number 112 of 2007 concerning the Arrangement and Development of Traditional Markets, Shopping Centers and Modern Stores, in CHAPTER I paragraph 5 it is explained that "Modern Stores are shops with self-service systems, selling various types of goods in retail in the form of minimarkets, supermarkets, department stores, 
hypermarkets or wholesalers in the form of wholesalers ". From the Presidential Regulation of the Republic of Indonesia, Number 112 of 2007 concerning the Arrangement and Development of Traditional Markets, Shopping Centers and Modern Stores, retail or retail traders can be classified into 4 forms: minimarkets, supermarkets, department stores, hypermarkets.

\section{RESEARCH METHODS}

The retail industry continues to experience rapid growth every year so that the existence of retail has the potential to erode small/traditional retailers. Also, changes in the shopping patterns of the public are increasingly following trends and also increasingly require the existence of modern retail. Therefore, it is necessary to have maximum performance for Retail Industry employees, maximum performance can be supported by an effective and ideal compensation system for these SMEs. The compensation obtained from these SMEs can be financial or nonfinancial. Using the salary mapping method to find out the compensation applied is good or not enough. Also, job grading is carried out using the job value and point system method. Also, the survey results will produce a critical position and compensable factor which will then form the basis for a survey on the decent living needs of retail sector workers. This will be based on the West Java governor's decision on the minimum wage. The results of this study are expected to provide suggestions for the sustainability of the Retail Industry in Bogor.

The study was conducted from October 2019 to May 2020 to obtain data on employee salaries and data on the needs for decent living in the retail sector in Bogor. The data was obtained from the results of questionnaires distributed online and offline. The sampling method uses nonprobability sampling (Monroy-Torres et al., 2010). with convenience for the data of 100 retail workers in Bogor. Taken using the Slovin formula (metode penelitian kuantitatif, kualitatif, dan R\&D, 2016).

\section{Data Analysis}

Data processing methods in the study are descriptive analysis, the four strategy framework (ERRC Grid), control chart, and gap analysis. Two ways can be used in the interpretation of data obtained by scale. One of them uses a numerical linear scale (Simamora, 2012). This study using a score of five that is converted into a percentage form, with the score is a positive pole $(100 \%)$, and one of the scores is a negative pole $(0 \%)$. The numerical linear scale can be formulated as follows:

Based on this formula, the measurement results through a semantic differential scale, with $\mathrm{m}=100 \%, \mathrm{n}=0 \%, \mathrm{~b}=5$ classes, it can be described as follows:

$$
R S=\frac{100 \%-0 \%}{5}=20 \%
$$

The results of these equations, the standards for five classes category are as follows: 


\begin{tabular}{lll}
\hline $0 \%-20 \%$ & $=$ & unfulfilled \\
$20 \%<\operatorname{mode}<40 \%$ & $=$ & somewhat unfulfilled \\
$40 \%<\operatorname{mode}<60 \%$ & $=$ & rather fulfilled \\
$60 \%<\operatorname{mode}<80 \%$ & $=$ & fulfilled \\
$80 \%<\operatorname{mode}<100 \%$ & $=$ & very fulfilled \\
\hline
\end{tabular}

Then to show the number of items that must be reviewed, the ERRC Grid is used. Grid Eliminate-Reduce-Raise-Create (ERRC) is a simple tool such as a matrix that encourages companies to focus simultaneously on eliminating and reducing, as well as improving and creating while opening a new blue ocean. To face competition by implementing this strategy, there are at least four actions that must be done by business people (Randall, 2015).

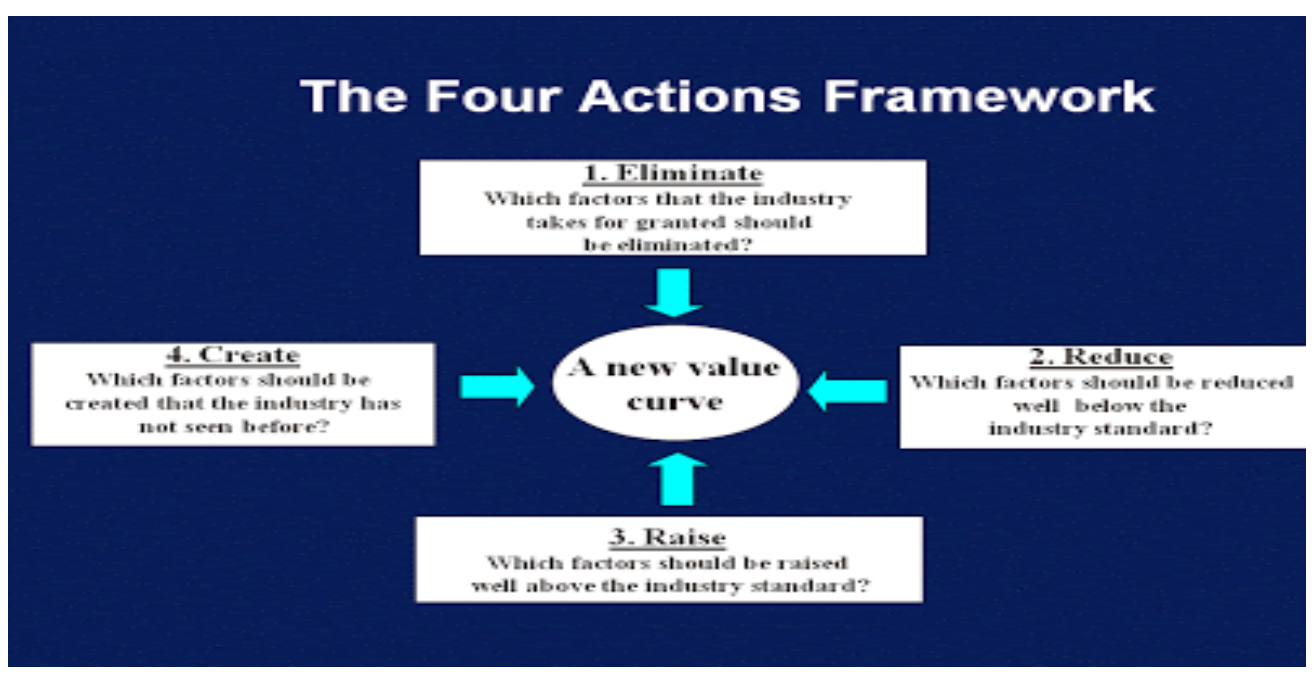

Figure 2

The Four Strategy Framework

\section{Eliminate}

In business, there will always be things that are considered good but not useful to the community. So, you should have to eliminate or eliminate things that have no value. This is done, to be able to maximize the features and parts available. In this case, there is no need to feel lost or feel something is missing if you eliminate it. In the case of research to eliminate or eliminate items on the necessities of a decent life that are considered unnecessary or needed or are at the $0 \%-20 \%$ fulfillment rate

\section{Reduce}

Different from elimination, reducing here is by reducing the element whose value is less but still needed. This is done if you want to eliminate the elements but not all. In the case of research to reduce items that are considered still lacking in terms of meeting needs workers because they are not yet a priority consumption of workers or are at the $20 \%$ fulfillment rate $<$ mode $<60 \%$. 


\section{Raise}

After reducing the elements that do not provide benefits, it is necessary to increase standards and also elements that have advantages. This will be an opportunity to make a difference. In the research case this is used for items that are $60 \%<$ mode $<80 \%$ fulfillment because they are considered to have almost met the criteria fulfilled.

\section{Create}

Actions that must be taken are creating new things that have never been done and done by new industries. Creating elements/features that are proven capable of providing more value and benefits. In the research case, this is used for items that are $>80 \%$ fulfillment. Also, in the discovery of new things for retail sectors such as the determination of the compensable factor, the formation of a new minimum wage, and others.

In this study the control chart is used to help detect any deviation by setting control limits, as follows (Kendall et al., 2016):

1. The upper control limit/UCL is the limit of a deviation that is still contested. UCL in the research there will be 2 types of decent living item and decent living expenditure.

$$
U C L=\overline{\bar{\chi}}+A_{3} \bar{S}
$$

2. The Center line/CL is the centerline which means there is no deviation of the characteristics sample.

$$
C L=\overline{\bar{x}}=\frac{\sum x}{N}
$$

3. The lower control line / LCL is the boundary line for all sample deviations. Like Ucl, in LCL also used there are 2 in terms of items and expenses.

$$
U C L=\overline{\bar{x}}-A_{3} \bar{S}
$$




\section{RESULTS AND DISCUSSION}

\section{The Result of a Descriptive Analysis of the Level of Fulfillment of Living Needs of Decent Workers}

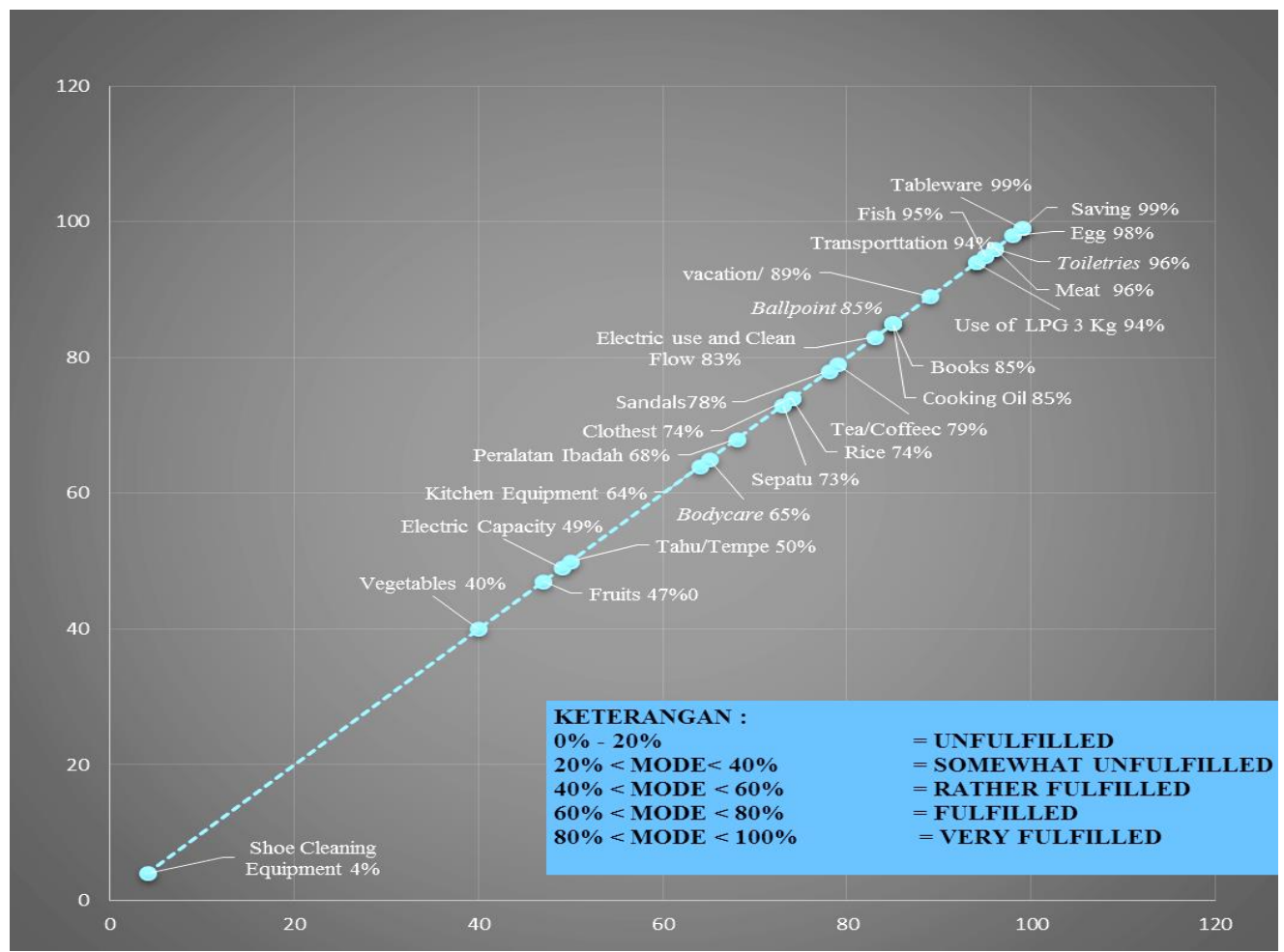

Figure 3

The Result of a Descriptive Analysis of the Level of Fulfillment of Living Needs of Decent Workers

The results of the analysis based on Figure 1 shows that the items that were asked to the worker were not fully fulfilled in meeting the needs of a worker's decent life. The level of fulfillment of a decent life is based on 5 criteria as described in the picture above. The criteria of "fulfilled" (60\% <Mode <80\%) and "very fulfilled" (80\% <Mode <100\%) are considered to have fulfilled the criteria to be a component of the needs of Decent Living (DL). Then, for the criteria of "somewhat fulfilled" (40\% <Mode <60\%) it is also considered to be a component of DL, but it is still necessary to do a review of both the criteria and quality/items on items whose level of fulfillment is at the level of somewhat fulfilled. . In the "somewhat unfulfilled" criteria ( $20 \%<$ Mode $<40 \%)$ a review should be carried out because it can hardly be fulfilled by Bogor retail industry workers. Finally, the criteria "not met" $(0 \%-20 \%)$ should also be reviewed or even eliminated these items because they are not a priority consumption of workers. Following are the results of a component analysis on the fulfillment of a decent life for Bogor retail industry workers. 


\section{Grid ERRC Strategy}

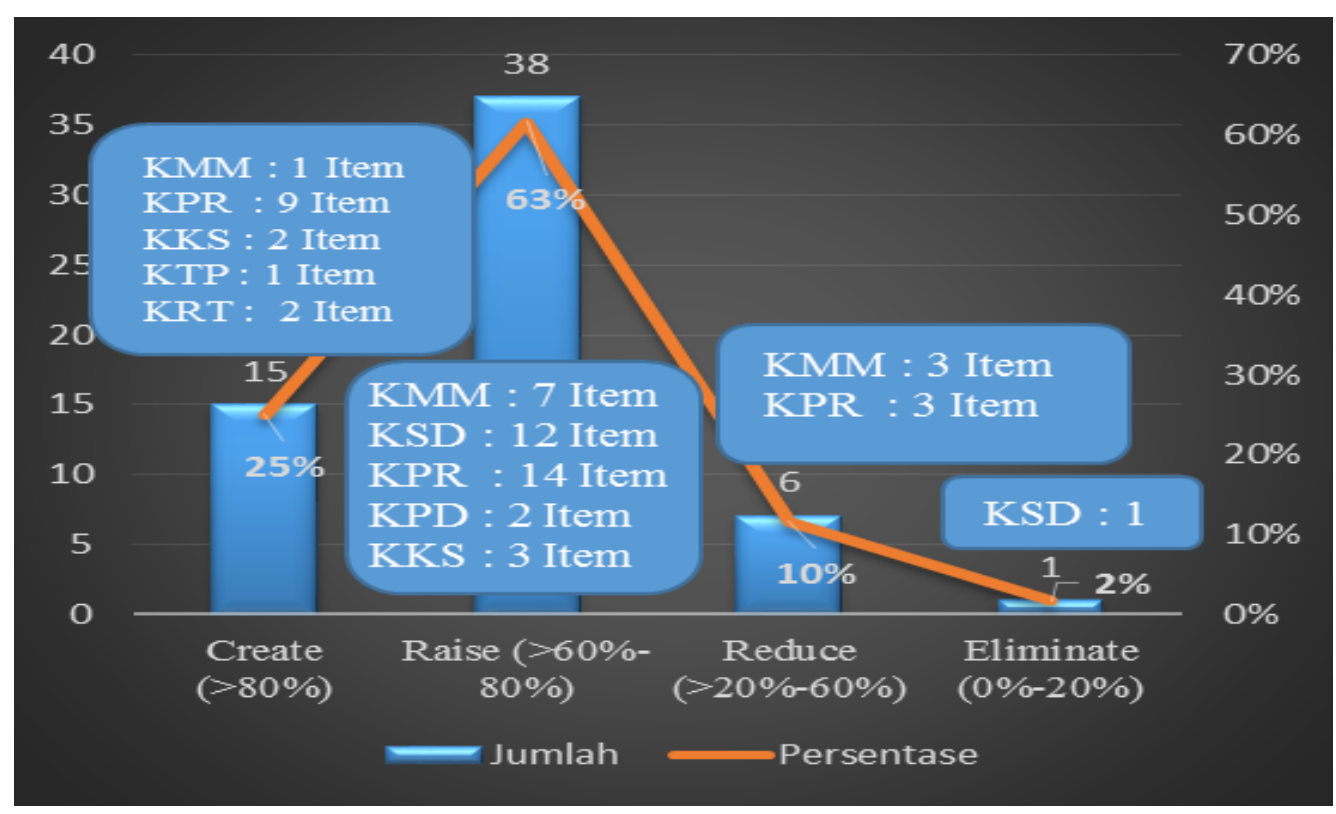

Figure 4

Compliance Based Comparison The Four Statrtegy Framework

Figure 2 shows the comparison of each DL component which can be concluded that 6 out of 60 items still need to be reviewed, the 6 items are nuts, fruits, vegetables, electrical capacity, iron, light bulbs, and rice/the cooker while the items on the eliminate graph need to be removed or no longer used, the item in question is the item shoe cleaning equipment. Then, the items on the raise chart show that the DL items are dominant on the graph, a set of items on the create chart indicate that $25 \%$ of the DL items can already be properly fulfilled by the workers. Descriptive analysis results, it was found that there is compensation that is in demand by retail industry employees in Bogor. These results can be seen in table 1, with a percentage of more than $10 \%$ as a benchmark in determining the compensation. Here is a description of some of the items:

a. The wages received by the Bogor retail industry workers as a whole are still insufficient for all items in the food and beverage component. However, when viewed from the percentage level of fulfillment, the Bogor retail industry workers prioritize meeting the needs of protein sources such as meat, fresh fish, and eggs. This indicates that a source of protein is an important requirement. In the table, it can also be seen that there are still several items that are in criteria that should need to be reviewed, such as nuts, fruits, and vegetables.

b. There are still many items in the clothing components that have been fulfilled. This indicates that the components with items of clothing, shoes, sandals, religious equipment can be used as components in the KHL of Bogor retail industry workers. However, the item of shoe cleaning equipment is not met 
which means that the item is not feasible and needs to be reviewed. Because in reality at work, workers are not required to wear shoes with synthetic leather quality.

c. Most of each item of housing needs have been met, although there are still some that are somewhat fulfilled criteria. This can be indicated that the items in the housing component can be used as a component of the necessities of a decent living except for items with somewhat fulfilled criteria which should be re-examined.

d. Fulfillment of transportation needs can be seen that in this component of the 100 respondents as many as $94 \%$ have met their needs in the transportation component. It can be indicated that the transportation component can be used as a component of the decent living needs of the Bogor retail industry workers. However, it would be better if a review was carried out related to the quality/criteria in this case because what was stated in the regulation of the Minister of Manpower and Transmigration the criteria for items of transportation was only public transportation. But in reality, many of the Bogor retail industry workers use private vehicles or in other words, do not use public transportation.

e. All items in the health component have been fulfilled following the quantity and quality contained in the regulation of the Minister of Manpower and Transmigration. However, several items contained in the regulations of the Minister of Manpower and Transmigration are combined into one source, such as deodorants, mosquito lotions, etc., are included in the body care category.

f. $\quad 89 \%$ of respondents' needs for recreation items have met their needs, and $99 \%$ of savings items have been able to save more than $2 \%$ of the wages received. From this explanation, it can be indicated that recreation and began components can be used as components of a decent living necessity for workers in the Bogor retail industry. 


\section{Statistical Process Control Analysis Results Using Control Chart}

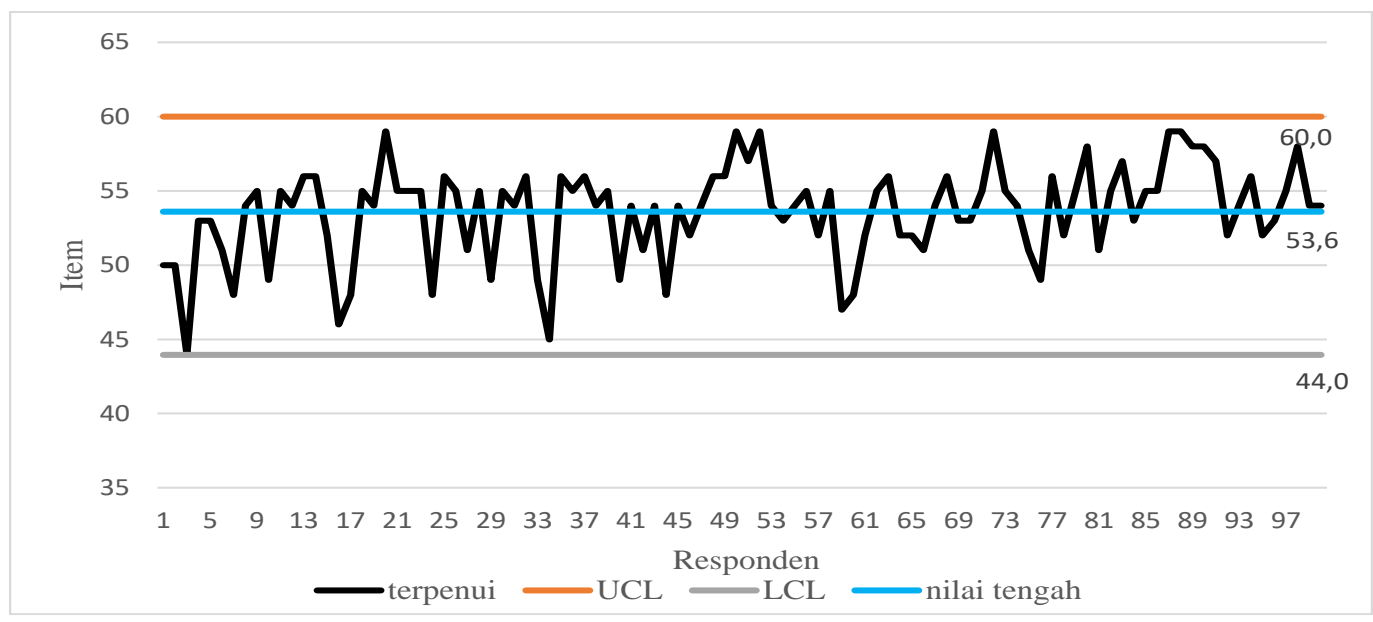

Figure 5

Control Chart Analysis Results Based on KHL Items

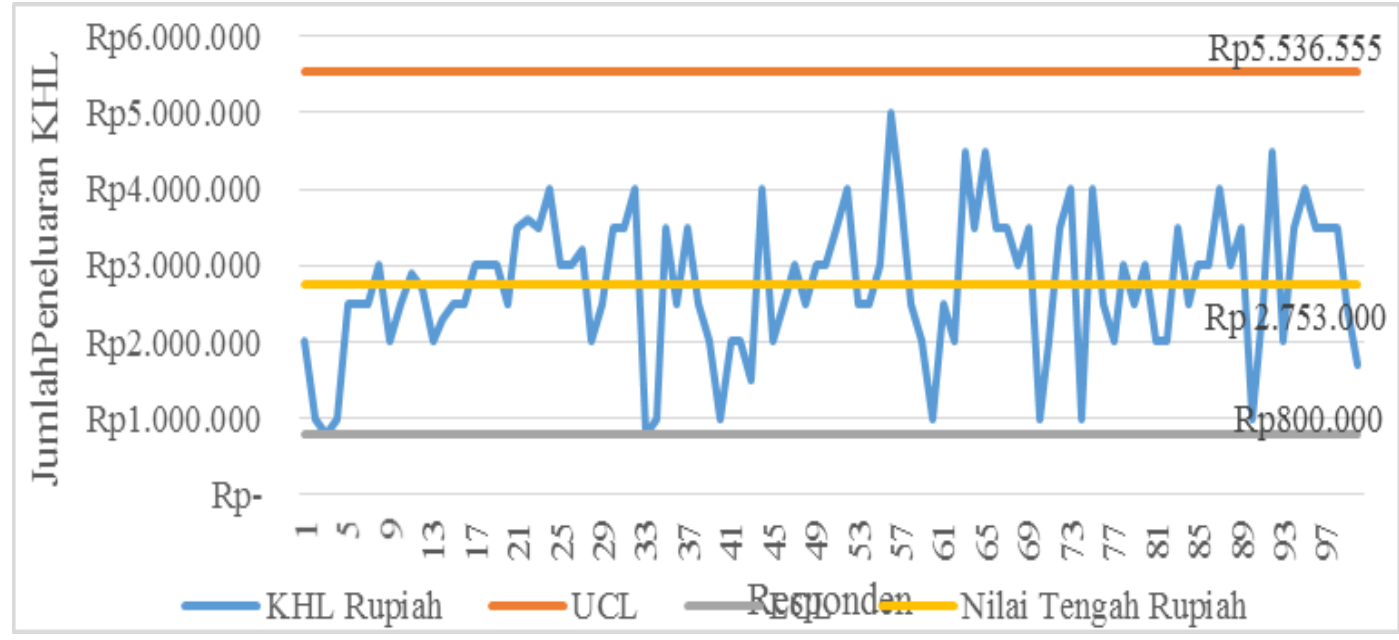

Figure 6

Control Chart Analysis Results Based on KHL Expenditure (IDR)

Based on the results of the analysis as shown in Figures 3 and 4, it can be concluded that there are no points that are outside the control limits. So it is within the control limits and does not require revision. From the results of the analysis, it can also be seen that in the control chart based on the items as in Figure 3 only 38\% of the total respondents whose DL number can be fulfilled above the average retail sector worker. While the analysis based on the amount of expenditure in rupiah is $50 \%$ above the average and $50 \%$ is below the average for expenditures for decent living needs of Bogor retail sector workers.

The results of the descriptive analysis prove that of the 60 items on the components of decent living, 7 of them should be reviewed or even eliminated, because it does not become a priority consumption for retail industry workers in 
Bogor. Therefore, the government should be paying attention to aspects of needs that should be an item in the components of the necessities of decent living. Then, the results of the descriptive analysis also found that the results of the study found that there was financial and non-financial compensation that were of interest to the workers, where the compensation should be re-considered by business actors so they could be met when they could not provide the appropriate wages.

Based on the results of the ERRC grid, this results in a new value curve aimed at the government, namely for the review of DL items in the reduce and eliminate categories and for business owners in the form of minimum wage recommendations, financial compensation, and non-financial priorities for workers. Then from the results of the control chart, although everything is still under control it still needs to be considered again, because the level of fulfillment above the average is still $38 \%$ which indicates it is still lacking. Therefore, the increase is still needed to be done by both the government and business actors.

\section{E. CONCLUSIONS}

The result of analysis descriptive and ERRC grid from 60 DL components, 53 of them have been fulfilled and the remaining 7 items are expected to be reviewed/written off. Besides, from the calculation of the average DL expenditure of workers, the Rationalization Minimum Wage resulting from the figure is IDR $2,753,000$, which is $28.1 \%$ below the UMK Bogor, which can be a reference for the Bogor regional government. For entrepreneurs financial compensation is considered the top priority for the retail industry to be fulfilled namely health benefits, holiday allowances, work accidents, and performance incentives as well as for non-financial compensation namely career systems, work facilities, responsibilities, employment status, working conditions.

From the DL analysis through the control chart obtained only $38 \%$ of the total respondents whose number of DL can be fulfilled above the average retail sector worker. While the results of the analysis based on total expenditure in rupiah are $50 \%$ above the average and 50\% are below the average. Besides, based on the results of the gap analysis, it can be seen that the distribution of workers' DL expenditure is $27 \%$ below the received wage. The researcher hopes that the Tripartite Communication Forum needs to consider or conduct a review of several components of decent living (KHL) such as shoe cleaning equipment and several items on food and beverage components, as well as housing components, so that the contents of the available components reflect priority consumption of workers, especially retail industry workers in Bogor, according to the topic of this study. 


\section{REFERENCES}

Badan Pusat Statistik. (2013). Statistik Indonesia 2013. In Katalog BPS.

Badan Pusat Statistika. (2020). Statistik Indonesia 2020 Statistical Yearbook of Indonesia 2020. Statistical Yearbook of Indonesia.

Bank Indonesia dan LPPI. (2015). Profil Bisnis Usaha Mikro, Kecil dan Menengah (UMKM). Bank Indonesia Dan LPPI.

Blazovich, J. L. (2013). Team identity and performance-based compensation effects on performance. Team Performance Management, 19(3), 153-184. https://doi.org/10.1108/TPM-11-2012-0035

Hasibuan, M. S. P. (2011). Manajemen Sumber Daya Manusia. Edisi Revisi Jakarta: Bumi Aksara.

Izzaty, \& Sari, R. (2013). Kebijakan Penetapan Upah Minimum di Indonesia. Jurnal Ekonomi Dan Kebijakan Publik.

Johnson, S. C., \& Distinguished, S. (2013). Retail Industry Snapshot. Retail Snapshot.

Kartika, L. (2020a). Designing Compensation System for Culinary Business : The Case of Bogor City, West Java Province, Indonesia. 141, 116-119.

Kartika, L. (2020b). Identification of Compensation System in Culinary Business : The Case of Bogor City, West Java Province, Indonesia. 141, 26-29.

Kendall, J. E., Kendall, K. E., \& Graue, C. (2016). QUALITATIVE DATA ANALYSIS Carolin. International Journal of Sales, Retailing and Marketing Special Issue: Research Methodology.

Menteri Tenaga Kerja Republik Indonesia. (2016). Peraturan Menteri Tenaga Kerja Republik Indonesia Nomor 27 Tahun 2016 Tentang Rencana Strategis Kementerian Ketenagakerjaan Tahun 2015-2019. Menteri Tenaga Kerja Republik Indonesia.

Monroy-Torres, R., Ramirez-Hernández, S. F., Guzmán-Barcenas, J., \& NavesSánchez, J. (2010). Comparison between five growth curves used in a public hospital. Revista de Investigacion Clinica; Organo Del Hospital de Enfermedades de La Nutricion.

Murty, W. A., \& Hudiwinarsih, G. (2012). PENGARUH KOMPENSASI, MOTIVASI DAN KOMITMEN ORGANISASIONAL TERHADAP KINERJA KARYAWAN BAGIAN AKUNTANSI (STUDI KASUS PADA PERUSAHAAN MANUFAKTUR DI SURABAYA). The Indonesian Accounting Review. https://doi.org/10.14414/tiar.v2i02.97

Randall, R. M. (2015). W. Chan Kim and renée mauborgne dispel blue ocean myths. Strategy and Leadership, 43(2), 11-14. https://doi.org/10.1108/SL01-2015-0007

Simamora, H. (2012). Akuntansi Manajemen. Edisi III. In Akuntansi Manajemen.

Sugiyono. (2012). Metode Penelitian Kuantitatif, Kualitatif dan R \& D.Bandung:Alfabeta. Metode Penelitian Kuantitatif, Kualitatif Dan $R$ \& D.Bandung:Alfabeta. https://doi.org/10.1017/CBO9781107415324.004 